\title{
Evaluation of susceptibility of pear and plum cultivars to winter frost
}

\author{
Shadan Khorshidi*, Gholamhossein Davarynejad, \\ Fahime Azmoode, Mehdi Kameli
}

Department of Horticultural Science Ferdowsi University Of Mashhad Mashhad, Iran

\begin{abstract}
The damage to pear and plum buds was investigated in Mashhad, after a period of unusually warm weather for a few days in March 2013 followed by a sudden drop in temperature to $-12^{\circ} \mathrm{C}$. Frost damages of vegetative and reproductive buds and spur-part below the buds of pear and plum cultivars were investigated based on visual observations. The following pear (Pyrus communis L.) cultivars were investigated: William's, Bell de june, Ida, Spadona, Koshia, Domkaj, Dare Gazi, Mohamad Ali, Boheme, Shekari, Ghodumi and one Asian pear (Pyrus serotina Rehd.). Japanese plum (P. salicina L.) included 'Shiro', 'Shams', 'Computi' and European plum (Prunus domestica L.) included 'Stanley', 'Early Santa Rosa', 'Late Santa Rosa', 'Shablon' and 'Black Diamond'. Electrical conductivity (EC) and proline content were measured in reproductive buds. It was discovered that visual damages were different between cultivars, as the vegetative pear bud of 'Ghodumi' suffered the most damage and all parts of 'Late Santa Rosa' were the most susceptible in plum cultivars. On the other hand, 'Computi' had the most resistant reproductive bud and no damage was observed in the other parts. The EC and proline content of 'Dare Gazi' were the highest despite the fact that high proline content did not show high resistance, which was related to the phenological stage of 'Dare Gazi'.
\end{abstract}

Key words: electrical conductivity; frost damage; proline content; visual observation

\section{INTRODUCTION}

Freeze injury to deciduous fruit crops can occur when the temperature dips below $0^{\circ} \mathrm{C}$. The extent of damage is directly related to cold intensity, duration and bud developmental stage. Other factors include plant's species, age, water content and general health. Young, actively growing, flowering, and/or dehydrated plants tend to be the most vulnerable to freezing temperatures (Stushnoff 1972).

Apple, pear, cherry and plum have flower buds with multiple flowers within a single bud. Fruit buds pass through up to eight developmental stages from fully dormant to full bloom (Larsen 2010). The critical temperature is defined as the temperature that buds and developing fruit can tolerate for half an hour before permanent damage occurs. Apricots, peaches, plums and sweet cherries in the pre-flowering stage have a killing temperature of $-5^{\circ} \mathrm{C}$. This rises to $-2.8^{\circ} \mathrm{C}$ in full bloom and $-1.1^{\circ} \mathrm{C}$ in the following bloom stage (Schalau 2005).

During an environmental stress like low temperatures, the osmotic regulation takes on a resistance role to cold by cell accumulation of

\footnotetext{
*Corresponding author.

Tel.: 00989153036220;

e-mail: khorshidi.shadan@gmail.com (Sh. Khorshidi).
} 
solutes such as proteins, polysaccharides, amino acids and lipids (Joshi et al. 2007). The sugar and proline content of cells increases in the dormancy phase while the starch concentration decreases (Aron et al. 2007). Proline prevents acidification and reduces cell stress. It accumulates in plants in response to biotic and abiotic stresses (Hare and Cress 2004). Leakage of electrolytes from plant cells commonly occurs after injury. This electrolyte leakage can be measured in terms of the electrical conductivity (EC) of the medium (Alavi Moghadam and Asgharzadeh 2014). Imani et al. (2011) found that in response to freeze stress, the electrolyte leakage of almond cultivar flowers increased. Other compounds acting as cryoprotectants include lipids, soluble proteins and free proline (Alavi Moghadam and Asgharzadeh 2014). Proline production increases in higher plants under stress conditions through Glutamate (nitrogen deficiency) and Urnetin (high content of nitrogen in plant cells) cycles. Visual ratings of injury and EC measurements of diffused electrolytes are the conventional methods for freeze injury evaluation (Palonen and Buszard 1997).

An unprecedented heat for a few days=followed by a sudden temperature drop to $-12^{\circ} \mathrm{C}$ on 9 March 2013 caused extensive damage to orchards, particularly drupes. In Khorasan Razavi, Iran the apricot damage reached up to $90 \%$, and up to $70 \%$ in peach, nectarine and plum cultivars. In addition, damage in ornamental plants such as the flower buds of Paulownia and one-year-old shoots of crape myrtle, Red Robin, privet, spindle and white cedar was observed. This study was conducted to evaluate different degrees of sensitivity to low temperature between different pear and plum cultivars at postdormancy in field conditions of Mashhad.

\section{MATERIAL AND METHODS}

The experiments were conducted during the winter season of 2013 in a commercial orchard, $43 \mathrm{~km}$ northwest of Mashhad, Iran located at $36^{\circ} 16^{\prime}$ and $59^{\circ} 38^{\prime}$ Lat/Lon and elevation of $990 \mathrm{~m}$ above sea level. Two separate experiments included twelve cultivars of pear: William's, Bell de june, Ida, Spadona, Koshia, Domkaj, Dare Gazi, Mohamad Ali, Boheme, Asian pear, Shekari and Ghodumi and eight plum cultivars (European: Prunus domestica L. Stanley, Early Santa Rosa, Late Santa Rosa, Shablon, Black Diamond; Japanese: P. salicina L. Shiro, Shams, Computi) were investigated. The one-year-old shoot samples from several 25 -yearold pear and 15-year-old plum trees were collected on March 11 $11^{\text {th }}, 2013$ in three directions of trees and sent to the laboratory. Minimum and maximum temperatures from February $19^{\text {th }}$ to March $20^{\text {th }}$ are presented in Figure 1. For most of the time the lowest temperature was not below zero in February and March until March $7^{\text {th }}$, when it reached $-5.2^{\circ} \mathrm{C}$, and the lowest one was $-12.2^{\circ} \mathrm{C}$ on March $9^{\text {th }}$.

\section{Observations of Visual Injury}

After $24 \mathrm{~h}$ keeping at laboratory temperature, a hundred vegetative and reproductive bud samples of each cultivar were visually evaluated for brown discoloration.

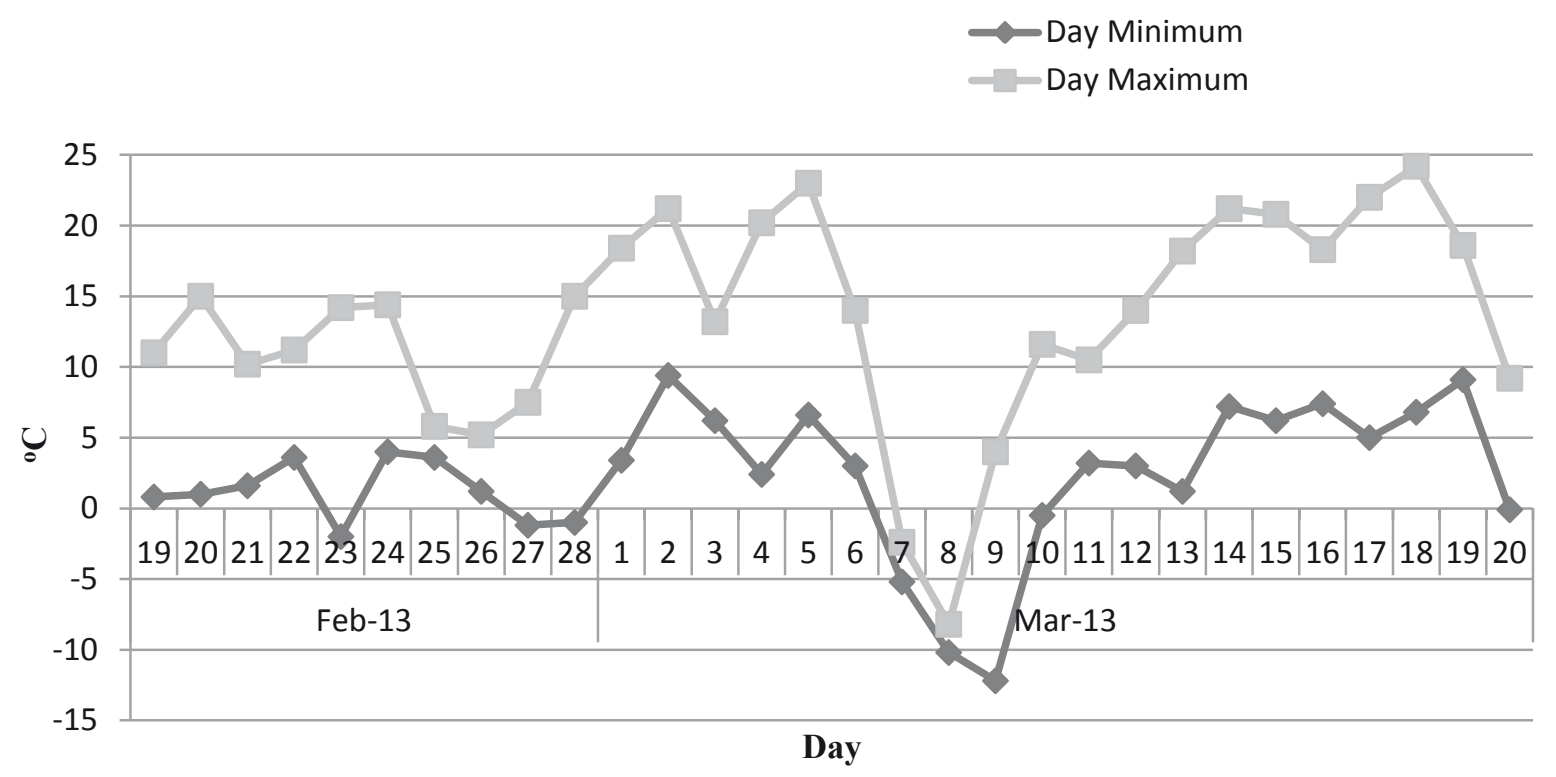

Figure 1. Date and minimum and maximum temperatures $\left({ }^{\circ} \mathrm{C}\right)$ during February and March 2013 


\section{Electrical Conductivity (EC)}

After the separating scale, reproductive buds were cut to $1 \mathrm{~cm}$ pieces and-immersed in $25 \mathrm{ml}$ distilled water for 24 hours at laboratory temperatures in a centrifuge tube. Afterwards, the initial electrical conductivity of each solution $\left(\mathrm{C}_{\mathrm{i}}\right)$ was measured with a Metrohm 644 digital conductivity meter. Sample tubes were then autoclaved $\left(20 \mathrm{~min}, 120^{\circ} \mathrm{C}\right.$, $1 \mathrm{~atm})$ to kill the tissues completely and after 12 hours electrical conductivity was measured again $\left(\mathrm{C}_{\text {autoc }}\right)$. Relative $\mathrm{EC}$ was calculated as:

$$
\mathrm{ECr}=\left(\mathrm{C}_{\mathrm{i}} / \mathrm{C}_{\text {autocl }}\right) \times 100 .
$$

\section{Proline Measurement}

The proline content of reproductive buds was measured by applying the method of Bates et al. (1973), using acid ninhydrin. One tenth of a gram of reproductive buds was homogenized with $10 \mathrm{ml}$ of $3.3 \%(\mathrm{~W} / \mathrm{V})$ sulfosalicylic acid aqueous solutions and centrifuged at $4000 \mathrm{rpm}, 4^{\circ} \mathrm{C}$ for $10 \mathrm{~min}$. Then $2 \mathrm{ml}$ acid ninhydrin and $2 \mathrm{ml}$ glacial acetic acid were added to $2 \mathrm{ml}$ of supernatant. The reaction mixture was boiled in a water bath for 1 hour. Four millilitres of toluene was added to the bathed reaction mixture and vortexed for 15 to 20 seconds. The upper phase containing proline was extracted, and the absorbance read at $520 \mathrm{~nm}$ by a UV-visible spectrophotometer.

\section{Statistical Analysis}

Results were analysed according to a completely randomized experimental design. Statistical analysis was carried out using MSTAT-C software. Mean values were compared using the least significance difference test (LSD) at $1 \%$ levels.

\section{RESULTS AND DISCUSSION}

\section{Visual Observations}

The least percentage of damaged vegetative buds was observed in 'Dare Gazi' (22.5\%). 'Boheme' and 'Ghodumi' suffered the most damage, while 'Ghodumi's reproductive buds were the least injured (13.35\%) (Fig. 2). In the case of plum trees, 'Late Santa Rosa' was the most sensitive in all parts and 'Computi' was found to be the most resistant and showed no damage in reproductive buds and spurs (Fig. 3). In all plum cultivars the pistil suffered more damage than the male part (Fig. 4). Choi et al. (1987) reported that the percentage of cold injury in flower bud was higher than other tissues, and the cold hardiness of pistil was weaker than stamen. Honty et al. (2008) found that pear cultivar Kaiser was the most susceptible to low temperatures both
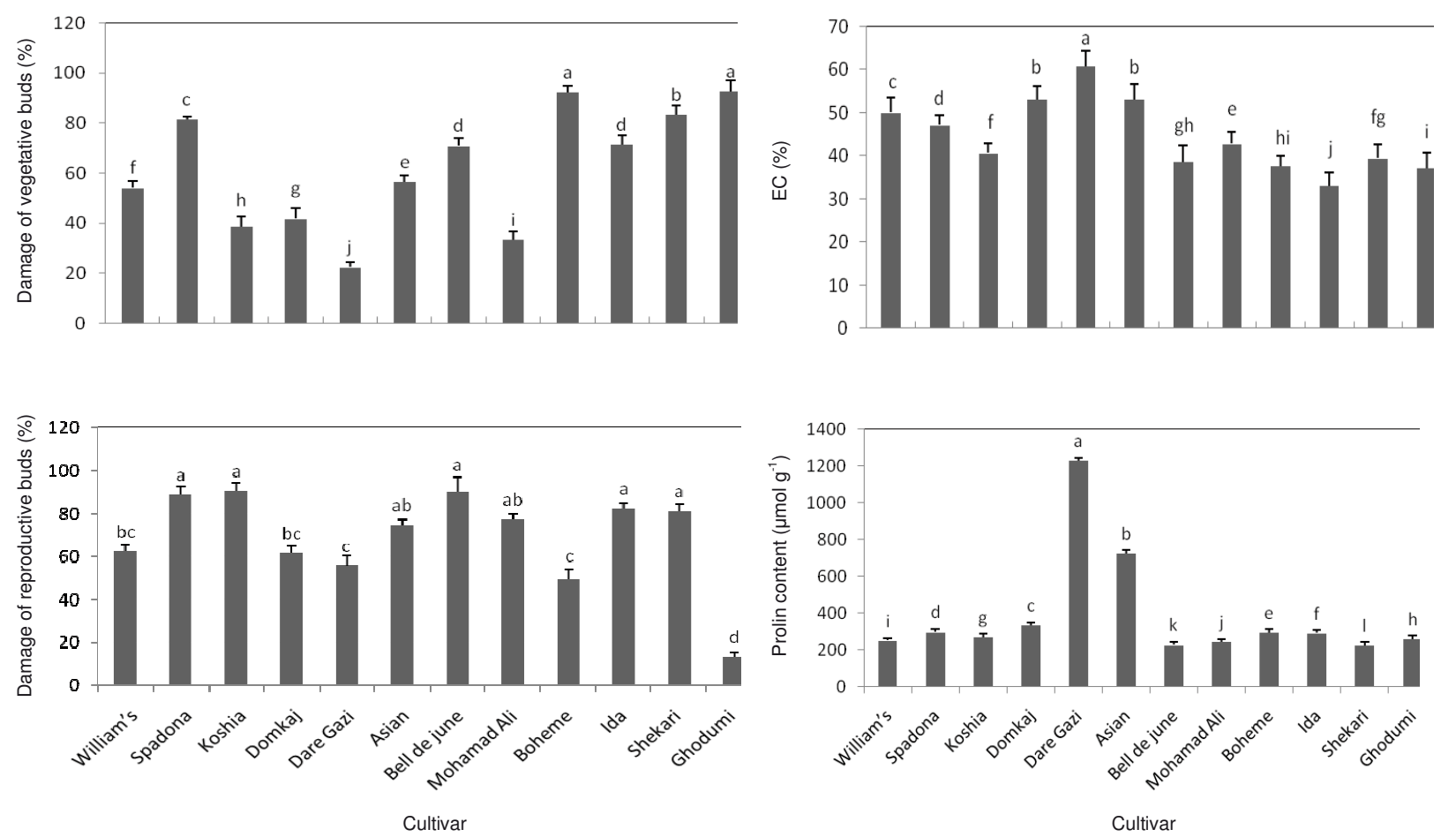

Figure 2. Percentage of frost damage of vegetative buds (\%), reproductive buds (\%), electrical conductivity (\%) and proline content $\left(\mu \mathrm{mol} \mathrm{g}{ }^{-1}\right)$ of reproductive buds of some pear cultivars. Each value is the mean $\pm \mathrm{SD}$ of three replicates. Different letters indicate significant differences at $\mathrm{p}=0.01$ separated by the LSD test 

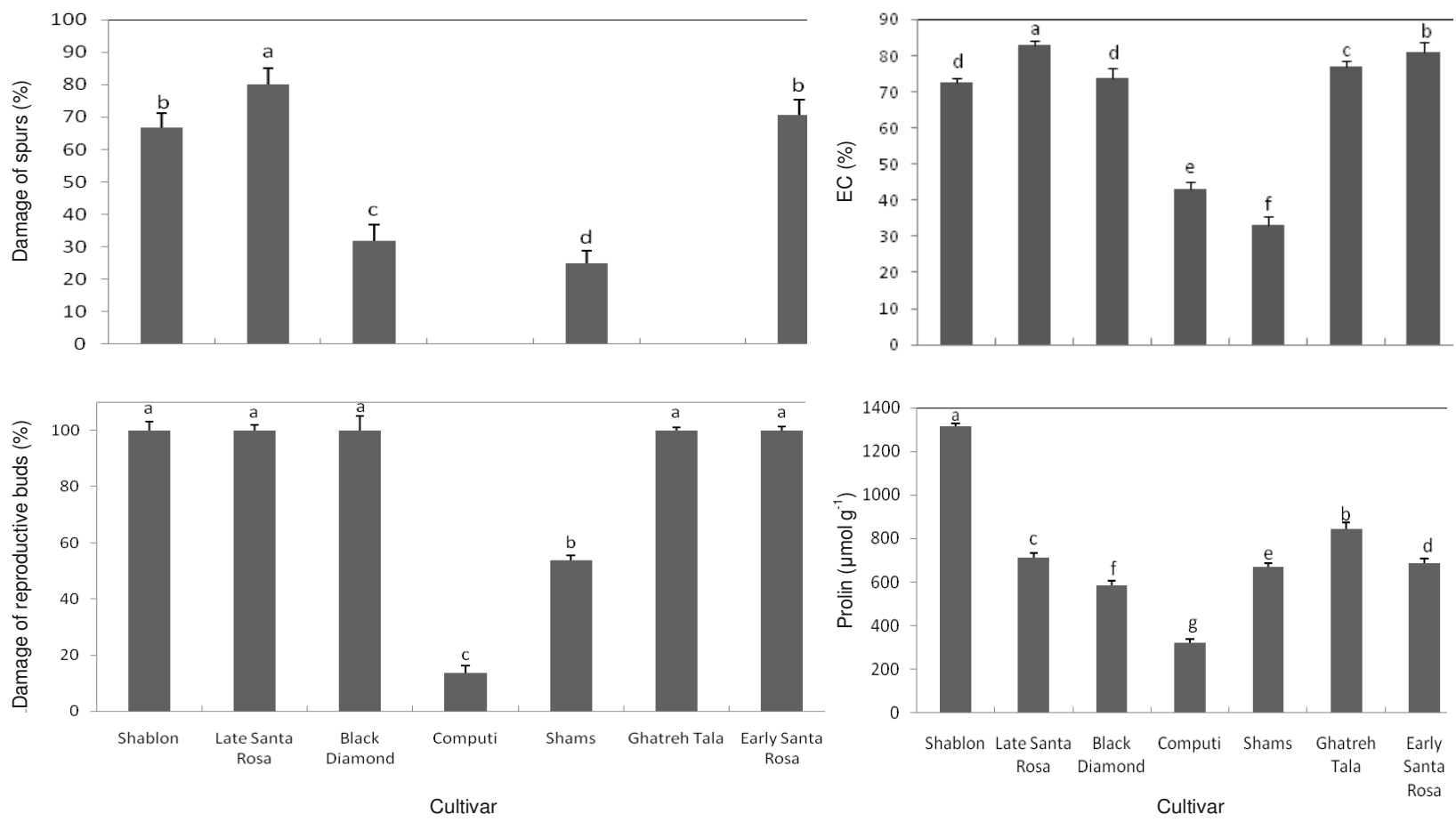

Figure 3. Percentage of frost damage of spurs (tissues below buds), reproductive buds, electrical conductivity (\%) and proline content $\left(\mu \mathrm{mol} \mathrm{g}{ }^{-1}\right)$ of reproductive buds of some plum cultivars. Each value is the mean $\pm \mathrm{SD}$ of three replicates. Different letters indicate significant differences at $\mathrm{p}=0.01$ separated by the LSD test

during endodormancy and ecodormancy, whereas 'Packham's Triumph' showed the lowest degree of frost damage as well as the least occurrence of death in every type of dormancy. Göndör and Tóth (1998) evaluated frost damage of 13 pear cultivars by microscopic examination of flower buds and found that 'Doyenné du Comice', 'Passe Crassane' and 'Doctor Jules Guyot' were sensitive to winter frost under Hungarian ecological conditions, while 'Packham's Triumph' was relatively resistant. Szalay et al. (2000) found that reproductive buds were the most sensitive part of the trees. Davarynejad et al. (2009) indicated that the most sensitive organ of walnut genotypes was female buds, followed by male buds, vegetative buds, annual shoots and finally biannual shoots. Palonen and Buszard (1997) indicated that flower bud hardiness of apples did not seem related to hardiness of woody tissue. In $P$. davidiana the shoot was hard, however, the reproductive bud was sensitive (Ackerman 1969).

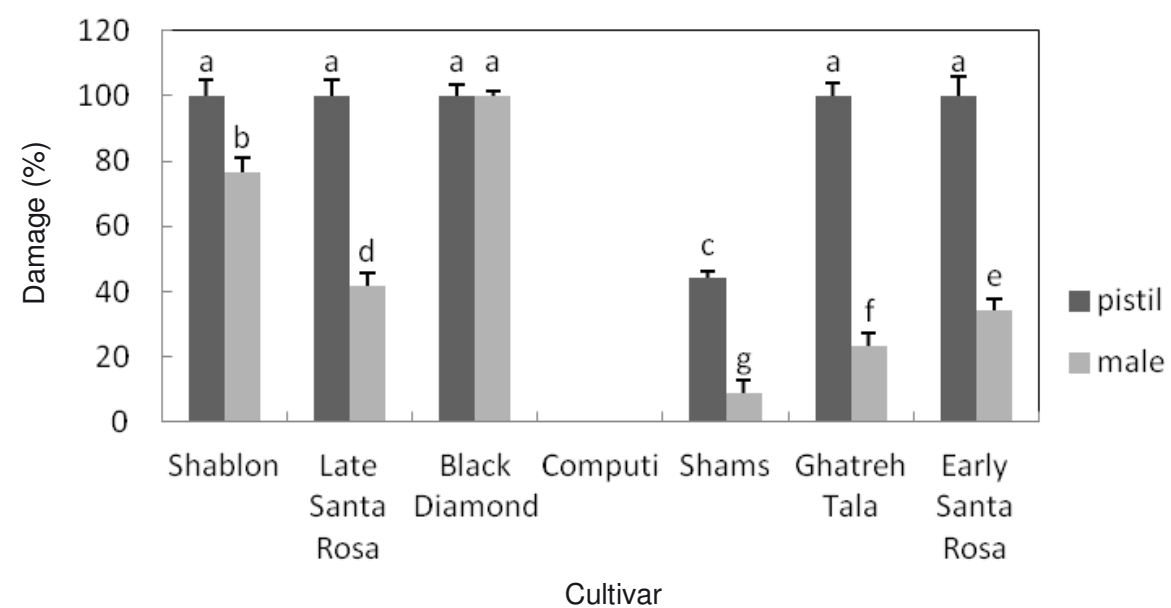

Different letters indicate significant differences at $\mathrm{p}=0.01$ separated by the LSD test

Figure 4. Percentage of frost damage of pistil and male organs of some plum cultivars 


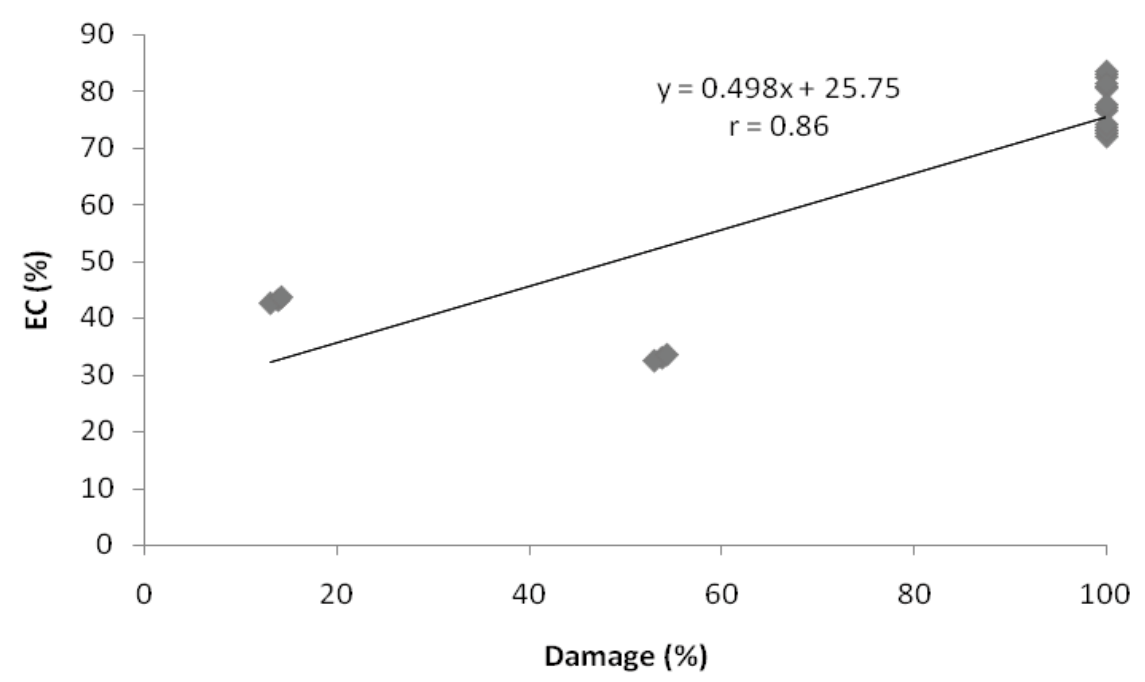

Figure 5. Correlation between EC and frost damage of some plum cultivars $(r=0.86)$

\section{Electrical conductivity (EC)}

There were significant differences among the electrical conductivity of plum and pear cultivars. The EC of 'Dare Gazi' pear was the highest (60.89\%) whereas 'Ida' was the lowest (33.15\%) (Fig. 2).

The Late Santa Rosa plum cultivar had the highest EC (82.94\%) and 'Shams' showed the lowest (32.93\%) (Fig. 3). A significantly high positive correlation was observed between EC and frost damage in plum cultivars (Fig. 5) $(r=0.86$, $\mathrm{p}<0.01$ ), which was consistent with the findings of Imani et al. (2011) about almond. Also, Ketchie et al. (1972) found a close correlation between electrolyte leakage and survival of pear seedlings evaluated visually by tissue browning, but this relation was not observed in our study. Davarynejad et al. (2009) found a correlation between electrolyte leakage values and visual observation of walnut flower buds.

\section{Proline Content}

The comparison of mean values of different pear cultivars on proline rate indicated that the highest proline rate was found in 'Dare Gazi' $(1229.38 \mu \mathrm{mol}$ $\mathrm{g}^{-1}$ ) and the lowest content was found in 'Shekari' (223.78 $\left.\mu \mathrm{mol} \mathrm{g}^{-1}\right)$ (Fig. 2). While having the highest proline content, the high EC values of 'Dare Gazi' indicates more damage vulnerability and susceptibility. There was a significant difference among plum cultivars in relation to proline content, as 'Shablon' had the highest proline content (1313.95 $\left.\mu \mathrm{mol} \mathrm{g}{ }^{-1}\right)$ and 'Computi' had the lowest rate (321.58 $\mu \mathrm{mol} \mathrm{g}^{-1}$ ) (Fig. 3). However, observation did not show any significant correlation between EC and proline content.
Barka and Audran (1997) investigated grape buds and shoots and found a high negative correlation between proline content and frost tolerance. Conversely, Nobari et al. (2012) stated that different pistachio cultivars fruit and leaves that were subjected to cold stress had more protein content than the control groups. Young (1977) indicated that proline increases did not correlate well with relative cold hardiness ratings of citrus rootstocks. 'Dare Gazi' as an early blooming cultivar had the most proline content, which agreed with the findings of Shoeiby et al. (2011) about pistachio, which had the highest proline content in the flower opening stage rather than swollen bud. Also Imani et al. (2012) found the highest proline rate in the anthesis stage and the lowest rate in the popcorn stage of sprout. In a sensitive plant, increased proline does not necessarily enhance resistance unless there is high proline content before stress (Yelonsky 1979). Yelonsky found that like sugar accumulations, proline accumulation does not reflect specific degrees of cold hardiness in citrus cultivars, which was consistent with our results. Nobari et al. (2012) reported that the amount of proline increased during phonological stages of pistachio cultivars. Duncan and Jack (1987) found that cell proline increase always doesn't cause an increase in cold resistance, which confirmed our results.

\section{CONCLUSIONS}

It seems that the high proline content of 'Dare Gazi' is due to its phonological stage, which was farther than other cultivars because it is an early blooming cultivar. 
Due to early warm weather during March, the dormancy of trees was broken sooner and 'Dare Gazi' was at a further phonological stage than the other cultivars as it showed the highest EC, which indicated tissue damage. However, visual observations did not show the highest amount of damage in 'Dare Gazi'.

Among plum cultivars, 'Computi' was the most resistant; however, it had the lowest proline content. This shows that the proline index is not appropriate for evaluating frost damage, but there was a high correlation was between EC and frost damage.

\section{REFERENCES}

ACKerman W.L., 1969. Fruit bud hardiness of North Caucasus seedlings and other foreign peach introductions. J. Fruit Var. Hort. Digest. 23: 14-16.

Alavi Moghadam H., Asgharzadeh A., 2014. Evaluation of freeing tolerance of five varieties of dutch roses. Ind. J. Fund. Appl. Life Sci. 4: 603-607.

Aron J., Suzanne M., Volenec J., Zachary J., 2007. Differences in freeze tolerance of zoysia grasses: carbohydrate and proline accumulation. Crop Sci. 47: 2170-2181.

BARKA E.A., Audran J.C., 1997. Response of champenoise grapevine to low temperature: changes of shoot and bud proline concentrations in response to low temperatures and correlations with freezing tolerance. Hort. Sci. 72: 557-582.

Bates L.S., Waldren R.P., Teare I.D., 1973. Rapid determination of free proline for water stress studies. Plant Soil 39: 205-208.

Chor J.C., Kim S.B., Moon J.Y., 1987. Study on coldinjury of three pear cultivars (Pyrus serotina Rehder) by low temperature treatment from Oct to Apr. Research Reports of the Rural Development Administration, Horticulture 28(1): 69-77.

Davarynejad G.H., Aryanpooya Z., Fahadan A., DAVARYNEJAD E., 2009. Evaluation of susceptibility of walnut genotypes to sudden cold and frost injury. J. Korean Soc. Hort. Sci. 50: 497-501.

DunCAN D.R., JACK M., 1987. Proline accumulation and its implication in cold tolerance of regenerable maize callus. Plant Physiol. 83: 703-708.

GöNDÖR M., Tо́тн M.G., 1998. Evaluation of frost resistance and productivity of pear cultivars in Hungary. Acta Hort. 484: 79-83.

Hare P.D., Cress W.A., 2004. Implications of stress induced proline accumulation in plant. Afr. J. Biotechnol. 9(7): 1008-1015.

Honty K., SÁrdi É., Stefanovits-Bányai É., Tóth M., 2008. Frost induced changes in enzyme activities and carbohydrate content in the spurs of some pear cultivars during the dormancy. Int. J. Hort. Sci. 14: 41-44.

Imani A., Barzegar K., Piripireivatlou S., 2011. Relationship between frost injury and ion leakage as an indicator of cold hardiness in 60 almond selections. Int J. Nuts Related Sci. 2: 22-26.

Imani A., Ezaddost M., Masoumi SH.,Raeisi I., 2012. Evaluation the resistance of almond to frost in controlled and field conditions. Int. J. Nuts Related Sci. 3: 29-36.

Joshi S.C., Chandra S., Palni L.M.S., 2007. Differences in photosynthetic characteristics and accumulation of osmoprotectants in saplings of evergreen plants grown inside and outside a glass house during the winter season. Photosynthetica 45(4): 594-600.

Ketchie D.O., Beeman C.H., Ballard A.L., 1972. Relationship of electrolytic conductance to cold injury and acclimation in fruit trees. J. Am. Soc. Hort. Sci. 97: 403-406.

LARSEN H.J., 2010. Evaluating tree fruit bud \& fruit damage from cold. Colorado State University.

Nobari F., Afshari H., Miri S.M., Hokmabadi H., 2012. An investigation of cold tolerance on chemical properties (proline, protein, and sugar) of the flower buds in four commercial cultivars of Damghan local pistachio. J. Nuts 3: 1-8.

Palonen P., Buszard D., 1997. Current state of cold hardiness research on fruit crops. Can. J. Plant Sci. 77: 399-420.

Schalau J., 2005. Freeze damage in fruit crops. Agriculture \& Natural Resources Arizona Cooperative Extension, Yavapai County.

Shoeiby M., Davarynejad G.H., Hokmabadi H., Tehranifar A., 2011. Investigation of proline, total protein content and soluble sugares during phonological stage of flower bud in pistachio cultivars. J. Hort. Sci. 25: 116-121.

STuSHNOFF C., 1972. Breeding and selection methods for cold hardiness in deciduous fruit crops. Hort. Sci. 7: 10-13.

Szalay L., Papp J., Szabó Z., 2000. Evaluation of frost tolerance of peach varieties in artificial freezing tests. Acta Hort. 538: 407-410.

Yelonsky G., 1979. Accumulation of free proline in citrus leaves during cold hardening of young tree in controlled temperature regimes. Plant Physiol. 64: 425-427.

Young R.H., 1977. The effect of rootstocks on citrus cold hardiness. Proc. Int. Soc. Citric. 2: 518-522.

Received July 10, 2014; accepted November 5, 2014 